\title{
How Government Agencies React to Termination Threats
}

Jostein Askim, Jens Blom-Hansen, Kurt Houlberg, Sфren Serritzlew

\begin{abstract}
Much research following Kaufman's classic study Are Government Organizations Immortal? has investigated the claim that government agencies enjoy great security and long life. Less attention has been paid to Kaufman's thesis that government agencies facing a termination threat have strong incentives to react. In a study of the on-going Norwegian local government amalgamation reform, we demonstrate that this type of government agency reacts by hoarding (i.e., a last-minute flurry of spending) when faced with a termination threat. This finding shows that agencies facing termination threats are active players in the termination game. We discuss implications for research on agency termination and design implications for reformers of the public sector.
\end{abstract}

\section{Introduction}

Conventional wisdom within political science and public administration has long held that government agencies are sticky. Once created, they remain (Downs 1967; Bardach 1976; Lowi 1979). In his path-breaking study Are Government Organizations Immortal? Herbert Kaufman (1976) found that agencies display impressive powers of endurance. However, he carefully spelled out his study's limitations, and ensuing research has qualified his findings. In an influential article, Lewis (2002) found that government agencies are, in fact, not immortal but face significant risks of termination. A large number of studies have investigated the reasons for the varying longevity of government agencies. The life and death of agencies depend on external factors such as political turnover, problem pressure, and budgetary 
constraints and on internal agency factors such as size, functions, and whether their origin lies in legislation or administrative decree (Adam et al. 2007; James et al. 2015; Kuipers et al. 2018; Moldogaziev et al. 2019).

Nevertheless, the literature on agency termination is still in its infancy. Keeping the focus firmly on the reasons for agency termination has led to important insights, but to the detriment of research on other important aspects of agency termination. As Carpenter and Lewis argued (2004, see also Dommett and Skelcher 2014), many other questions require scholarly attention, not least agency strategy - that is, how agencies threatened with termination react. Actually, focusing on agency strategy takes us back to one intriguing, but forgotten, insight in Kaufman's classic study:

[Government organizations] are not helpless, passive pawns in the game of politics as it affects their lives; they are active, energetic, persistent participants. The motives of their leaders and members to preserve the organizations to which they belong are very strong. The techniques they can use are abundant, and their experience in using them is extensive (Kaufman 1976, 9).

Kaufman's call for studying agency strategy has not been heeded in subsequent research. Agencies faced with termination, or a threat of termination, might seek to preserve themselves but they might also, for example, unleash a flurry of spending activity. To understand agency policy at the potentially last stages of their existence, it is necessary to expand Kaufman's argument by analyzing the incentive structure of the existentially threatened agency.

However, literature on agency termination needs expansion not only of theory, but also of methods. Scholars face a non-trivial methodological challenge: Agency termination might occur more frequently than commonly thought. But exactly how frequently termination 
occurs is disputed in the literature, not least because authors define the phenomenon differently. But empirically comparable cases are still relatively rare and, worse, cases are often non-comparable in two ways. First, agencies have different functions, are organized at different levels of government, and have different governance structures. They are therefore often not truly "comparable" in Lijphart's (1971) sense of the word. As Bardach noted (1976, 123), "[o]ne always suspects each instance of the phenomenon is bound to be so idiosyncratic that no interesting generalizations will be possible." Second, the concept of termination is elusive. As Kuipers et al. noted $(2018,267)$, agencies are subjected to various kinds of reorganization, "which blurs the distinction between termination or continuation in a dressed up (or down) version." Given this definitional uncertainty, analysts might succumb to “conceptual stretching” (Sartori 1970) to collect enough cases for statistical analysis.

To overcome these obstacles to rigorous hypothesis testing requires creative thinking. We seek to contribute both theoretically and methodologically. First, to add to the theoretical understanding of agency terminations, we shift attention from external factors and agency characteristics to agency strategy. Following Kaufman's forgotten call, our research question is as follows: How do agencies react when threatened with termination? We develop a game theoretic model of the short-term incentive effects unleashed by termination threats in the period between the decision and implementation phases of the termination. This period is crucial to understand because it creates incentives for short-term strategic positioning, to act "before it is too late."

Second, we seek to overcome the methodological rare-event problem - the fact that agency terminations do not normally occur in a comparable way among a large set of comparable units. We do not follow the strategy adopted by, for example, Carpenter and Lewis (2004) and van Witteloostuijn et al. (2018), that is, to deal with heterogeneous cases by adding control variables to statistical tests. Instead, we shift attention from the usual type of 
data - national government agencies - to an empirical testing ground not plagued by the rareevent problem, namely, local governments. In most countries, municipalities are numerous and constitute comparable units. Furthermore, in most countries, municipalities have been merged into larger units over the past fifty years (Blom-Hansen et al. 2016). As we argue below, mergers fall within most definitions of agency termination. The advantage of using this specific example is that municipal merger holds constant the type of termination and thus makes it possible to avoid stretching the termination concept. Comprehensive municipal merger reforms therefore constitute an attractive and hitherto unexploited empirical testing ground for agency termination scholarship.

Our research setting is the Norwegian local government amalgamation reform that started in 2014. The national government emphasized voluntariness but we use the fact that municipalities faced territorial uncertainty because they could not be confident they would not be amalgamated involuntarily. From the beginning, the government indicated that forced amalgamation could occur. We apply a difference-in-difference logic and compare economic policy before and after the reform began across municipalities never seriously considered for merger, municipalities that volunteered to merge (with someone specific or just with anybody), and municipalities facing a threat of being forcedly merged.

Short-term strategic positioning obviously has many forms. One related to economic policy is hoarding, defined as last-minute changes in economic policy to maximize benefits for the agency's current stakeholders before "shutdown." In the context of the merging of municipalities, hoarding is understood as municipal spending beyond that which would otherwise be the case, greater spending driven by the expectation that municipalities can keep benefits for their present citizenry while sharing costs with others in the amalgamated entity. Setting resources aside in the present - to save - is not hoarding in this context, because the decision on allocating those resources would then be made in the future by the amalgamated 
entity collectively, with uncertain benefits for the present municipality. For a municipality whose response to merger is to maximize benefits for its present citizenry and territory, the hoarding strategy is rather "spend now, while we have the opportunity."

The results show that agency strategy is an important factor in agency terminations. Even a threat of termination unleashes strong internal forces and strategic positioning.

We begin by elaborating agency termination scholarship's methodological challenges and by advocating using local government mergers as cases of agency termination. We then expand Kaufman's argument by analyzing the incentive structure of agencies facing termination in a game theoretic model of the strategies of agencies facing termination. Since we study agencies having an elected political leadership, we rely on the literature on common pool problems. Next, we describe the research setting and the data and methods. Then we present the results and conclude by discussing the results' implications for agency termination scholarship.

\section{Local Government Mergers as Agency Terminations}

The empirical literature on agency termination faces two methodological challenges. The first is conceptual: What counts as a termination? Agencies are frequently reorganized, but when are reorganizations so fundamental that agencies cease to exist and can be classified as terminated? This problem is widely discussed (Rolland and Roness 2011; Kuipers et al. 2018; Adam et al. 2007). Kaufman (1976, 23-33) discussed it at length and settled on a definition focusing on organizational boundaries. This definition, however, has not caught on. Subsequent research has relied on different definitions focusing on different types of reorganizations, including changes in governance structures, agency names, locations, and 
functions; mergers, splits, absorptions, and replacements. Box 1 lists definitions used in five prominent studies.

(Box 1 about here)

The problem is that definitions of termination used in the literature are often so broad that they include substantively different situations. We conjecture that rigorous hypothesis testing is facilitated by more stringently defining termination. In our empirical study, we focus on mergers. This type of termination falls clearly within Kaufman's original definition focusing on organizational boundaries and is recognized by almost all subsequent studies.

The second methodological challenge is that the term "agency" does not denote a precisely defined government unit. Kaufman (1976) did not have one type of agency or one level of government in mind but instead discussed government agencies in the broadest sense of the word. He used expressions like agencies, bureaus, organizations, and departments interchangeably. ${ }^{1}$ His decision to include only agencies under US federal executive departments in his study was based on practical, not theoretical, reasons. Subsequent research has not discussed the agency concept in depth but often pragmatically relied on official lists of agencies, such as the United States Government Manual (e.g., Peters and Hogwood 1988; Lewis 2002; Boin et al. 2010, 2017; van Witteloostuijn et al. 2018), the Irish State Administration Database (Maccarthaigh 2014), or the UK Civil Service Statistics (James et al. 2015). The result has often been that data sets encompass a varied group of agencies. Box 2 lists the types of agencies included in five prominent studies.

\section{(Box 2 about here)}

\footnotetext{
${ }^{1}$ Kaufman's use of the concept "agency" is thus much broader than is sometimes the case today, where "agencies" might refer more narrowly to organizations structurally disaggregated from their ministries and operating at arm's-length from the government (Verhoest et al. 2012).
} 
The problem is that assuming unit homogeneity in data sets comprising very different types of agencies is not always defensible (King et al. 1994, 91-4). Somehow, the included agencies' heterogeneous nature must be considered to avoid omitted variable bias. This is readily acknowledged in the literature and dealt with by introducing variables to control for different types of agencies. In principle, this is a fine strategy, but in practice, controls often must rely on crude categorizations of agencies. ${ }^{2}$ Given the wide variety of real-world agencies, we again conjecture that rigorous hypothesis testing is better facilitated by a more stringent comparative case design. We therefore focus on a specific type of government agency (understood in Kaufman's broad sense), namely local governments in one country.

Globally, local governments are as varied as the population of agencies. Like other agencies, some local governments have limited policy portfolios (e.g., US school districts), while others are responsible for a broad range of policy areas (e.g., Dutch municipalities). Like other agencies, local governments are typically governed by a board. It might be directly elected (e.g., UK local councils), or appointed (e.g., Estonian counties). Like other agencies, some local governments have independent income sources (e.g., Swedish municipalities), while others rely on central government funding (e.g., Danish regions). Like other agencies, some local governments are territorially defined (e.g., French communes), while others are functionally defined (e.g., US single-purpose municipalities). However, local governments within one country are comparable in various ways, such as functions, governance structures, and financing. They are, in other words, relatively homogeneous units. In addition, they are often numerous. From a methodological perspective, such an empirical field is therefore attractive. Although agency termination has mostly been studied at the national level, there is no theoretical reason why the phenomenon should not be studied at other levels. Indeed,

\footnotetext{
${ }^{2}$ One example is Lewis $(2002,96)$, who controls for the following agency characteristics: whether the agency was designed to be temporary, whether it was created by legislative action, and the agency's size. Another example is James et al. (2015, 772-3), who control for the agency's primary function, for whether the agency is a successor to a distinct previous organization, and for the agency's size and budget.
} 
studying lower levels of government is recommended by Adam et al. (2007) in their literature review.

In sum, our take on the two methodological problems is to study one type of termination in one type of agency. This is a big challenge to overcome in a large- $\mathrm{N}$ setting, but local government mergers do so. We now turn to theorizing how Kaufman's (1976) notion of agency strategy plays out in this context.

\section{Strategies of Agencies Facing Termination: A Game Theoretic Model}

The literature on agency termination has shown that agencies are in fact mortal and that mortality depends on both internal and external factors. The focus has almost exclusively been on the antecedents of agency termination. However, the risk of termination not only gives agencies reason to fight to preserve themselves; it might also prompt agencies to change policy before it is too late. However, how agencies actually change policy depends on the incentives they face.

These incentives, we argue, depend on the type of termination, the certainty of the termination, and the preference for termination. We build our argument on the common pool problem. In general, the common pool problem arises when costs of an activity that benefits a small group are shared among a larger group (Hardin 1968; Ostrom 1990). In that case, the small group has an incentive to engage in the activity, even though it might be harmful for the larger, collective group. When an agency faces termination, it can choose to engage in hoarding, even when this is inefficient for the collective (this will exploit the common pool), or choose not to engage in hoarding (this will preserve the common pool). The basic insight from the common pool literature, of course, is that common pools tend to be exploited (Weingast et al. 1981), in this case because benefits of hoarding fall upon the agency facing termination, while benefits of future spending fall upon a larger group. 
The problem can be formalized in a game theoretic model whose basic logic is as follows: Public agencies can often benefit from having a buffer for future spending, meaning that agencies will typically not spend all available resources immediately. Saving some resources for future spending is attractive if the present value of spending later exceeds the value of spending immediately. However, agencies risking termination will discount the present value of future spending, because of the likelihood that they will in fact not exist in the future and hence be incapable of spending the resources. This knowledge can lead the agency to resort to hoarding.

Formally, we define $\mathrm{M}_{\mathrm{i}}$ as the payoff to agency $i$, (i.e., the present value to an agency of resources spent today and later). We first consider an agency not facing termination. The model describes the decision to spend today or later. For simplicity, we assume that the agency faces a discrete choice between two strategies, $S_{1}=$ Save (postpone spending of a fixed amount) or $\mathrm{S}_{2}=$ Spend (spend a fixed amount today). If agency $i$ chooses to save, $\mathrm{M}_{\mathrm{i}}\left(\mathrm{S}_{1}\right)$ $=\mathrm{a}$, where $a$ is the present value to the agency of a future payoff from future spending of the fixed amount. If agency $i$ chooses to spend (i.e., not to postpone any spending), $\mathrm{M}_{\mathrm{i}}\left(\mathrm{S}_{2}\right)=\mathrm{b}$, where $b$ is the present value to the agency of spending the fixed amount now. A rational agency will save if $\mathrm{M}_{\mathrm{i}}\left(\mathrm{S}_{1}\right)>\mathrm{M}_{\mathrm{i}}\left(\mathrm{S}_{2}\right) \Rightarrow \mathrm{a}>b$. When $\mathrm{a}>b$, the agency prefers to save because the present value of future spending exceeds the value of spending now. When $b>\mathrm{a}$, on the other hand, the agency will prefer to spend resources now.

Now consider the scenario wherein the agency knows it will be terminated. If an agency is to be terminated, $a$ (the value of future spending) might be lost entirely. The value of future spending might also be considerable. Consider for example the termination of a municipality. In 2020, Os Municipality ceases to exist in Norway. It will be amalgamated with Fusa Municipality. However, of the 24,493 citizens in the resulting new, amalgamated municipality Bjørnafjorden, 20,573 - more than 80\% - used to live in Os. Postponed 
spending would therefore benefit stakeholders of Os considerably. In general, an agency $i$ that will be terminated will discount $a$ by a factor $\mathrm{d}_{\mathrm{i}} \in[0 ; 1]$. If the postponed spending is of no value, $d_{i}=0$, and if it is of full value, $d_{i}=1$. In the case of termination by amalgamation, it is easy to account for $\mathrm{d}$. $\mathrm{d}$ is then simply the terminated agency's share of the new agency. In the case of municipalities, if a municipality A having 10,000 citizens is to be amalgamated with a municipality B having 40,000 citizens, stakeholders of A will benefit proportionately from the postponed spending. In this case, $d_{A}$ will be $10,000 /(10,000+40,000)=0.2$ and $d_{B}=1-d_{A}$ $=0.8$.

This 'game of termination' is illustrated in Figure 1 in strategic form. The four cells correspond to combinations of strategies of $\mathrm{A}$ and $\mathrm{B}$. The expression above the slash represents the payoff for agency A; the expression below represents the payoff for agency B. For example, the payoff for agency A of spending if agency B saves can be found above the slash in the top-right cell: $\mathrm{M}_{\mathrm{A}}\left(\mathrm{S}_{2}, \mathrm{~s}_{1}\right)=\mathrm{b}+\mathrm{d}_{\mathrm{A}} \mathrm{a}$. In this case, agency A receives $b$ because it chooses to spend the fixed amount now, and, since B saves, A will benefit from this in the amalgamated agency by its share $d_{A}$. If both agencies save (top-left cell), $M_{A}\left(S_{1}, s_{1}\right)=d_{A} a+$ $d_{A} a$. A will benefit proportionately from the value of both A's and B's savings, a. If agency A saves and $B$ spends (bottom-left cell), $M_{A}\left(S_{1}, s_{2}\right)=d_{A} a$ (A does not benefit from $B$, since $B$ spends now, but A does benefit from its own postponed spending, discounted by $\mathrm{d}_{\mathrm{A}}$ ). Finally, if both agencies spend, $\mathrm{M}_{\mathrm{A}}\left(\mathrm{S}_{2}, \mathrm{~s}_{2}\right)=\mathrm{b}$. Since the game is symmetric, payoffs are similar for $\mathrm{B}$.

\section{(Figure 1 about here)}

If two municipalities of equal size are to be terminated by amalgamation, $d_{A}=d_{B}=0.5$. In that case, $M_{A}\left(S_{1}, s_{1}\right)=M_{B}\left(S_{1}, s_{1}\right)=a$. To solve the game, we first assume that $B$ saves. We then compare $M_{A}\left(S_{1}, s_{1}\right)$ with $M_{A}\left(S_{2}, s_{1}\right)$. A will spend if $M_{A}\left(S_{2}, s_{1}\right)>M_{A}\left(S_{1}, s_{1}\right) \Rightarrow b+d_{A} a>$ $d_{A} a+d_{A} a \Rightarrow b>d_{A} a$. We then assume that $B$ spends, and compare $M_{A}\left(S_{1}, s_{2}\right)$ with $M_{A}\left(S_{2}, s_{2}\right)$. 
A will spend if $M_{A}\left(S_{2}, s_{2}\right)>M_{A}\left(S_{1}, s_{2}\right) \Rightarrow b>d_{A}$ a. In other words, $S_{2}$ is a dominant strategy if $\mathrm{b}>\mathrm{d}_{\mathrm{A}} \mathrm{a}$, and due to symmetry, $\left(\mathrm{S}_{2}, \mathrm{~s}_{2}\right)-$ or Spend / spend - is a Nash equilibrium under that condition. In practical terms, this shows that termination threats lead to hoarding, unless the present value of future spending is very high (twice as high as b in the simple model with two amalgamating agencies of equal size).

In the simpler type of termination involving no amalgamation, the payoff to A does not depend on the actions of $B: M_{A}\left(S_{1} ; s_{1}\right)=M_{A}\left(S_{1} ; s_{2}\right)=d_{A}$ and $M_{A}\left(S_{2} ; s_{1}\right)=M_{A}\left(S_{2} ; s_{2}\right)=b$. A will spend if $b>d_{A} a$ and the equilibrium is the same.

Agencies are seldom certain about termination. Typically, an agency must make spending decisions under uncertainty. Relaxing the assumption of certainty, we let $\mathrm{p}$ indicate the probability that termination will happen. Now, the present value of saving is probabilistic. In the appendix (Figure A1), we extend the game theoretic model to consider uncertainty. We show that spending is a dominant strategy if $b>(1-p) a+p d_{A}$ a for both agencies and hence $a$ Nash equilibrium. In practical terms, this shows that termination threats lead to hoarding, and that this tendency is stronger the larger the value of $p$ (since when $p$ increases, $(1-p) a+p d_{A} a$ decreases when $\left.d_{A}<1\right)$. Or, in other words, greater certainty about termination increases the likelihood of hoarding.

Summing up, the game theoretic model leads to two expectations. First, termination threats will increase hoarding. Second, a higher probability of termination leads to more hoarding. This logic is general and also applies to municipalities. The importance of the common pool problem for municipal mergers is well-documented (Blom-Hansen 2010; Hansen 2014; Hinnerich 2009; Hirota and Yunoue 2017; Saarimaa and Tukiainen 2015). Until the moment a municipality is terminated (by amalgamation), it has an opportunity to deplete the common pool by increasing spending. Benefits from the increased spending fall upon the constituency of the present political leadership, but costs will be borne by the 
constituency of future political leaderships. We argue that decision makers in municipalities faced with threats of termination have incentives to engage in hoarding, and that the higher the likelihood of termination, the larger the incentives.

Going beyond the assumptions of the game theoretic model, we now turn to discussing the local preference for amalgamation in municipalities. This might seem to be a constant; surely, nobody wants to be terminated. Recall, however, that agency termination does not necessarily mean annihilating an agency. This also goes for radical reorganizations such as amalgamations. Constituents of a given municipality might see an upcoming amalgamation as an unwanted termination. Local councilors and bureaucrats fear losing their jobs and the citizenry fear losing their local identity. Constituents of another municipality, however, might perceive amalgamation as a wanted de facto continuation, or even an improvement, of the status quo; they might see an amalgamation as the beginning of something new and better that requires eliminating something else (Bardach 1976, 126). We therefore expect that hoarding will be less widespread in municipalities voluntarily entering into a municipal amalgamation than in municipalities facing a potential forced amalgamation.

Combining these arguments, and applying them to municipal amalgamation, we can distinguish between six conditions, based on the probability of and preference for the amalgamation. We show them in Table 1. Using the game theoretic model, we hypothesize that hoarding is high when amalgamation is certain (cell A of Table 1), medium when it has an intermediate probability (cell B), and low when amalgamation has 0 probability (cell C).

(Table 1 about here) 
When amalgamation is forced, we expect hoarding to be higher. Hence, we expect more hoarding in cell D than in cell A. Similarly, we expect hoarding in cell E to be higher than in $\mathrm{B}$, and hoarding in $\mathrm{F}$ higher than in $\mathrm{C}$.

Focusing on these two factors - certainty and preference - refines the common pool logic and expands Kaufman's (1976) argument on agency strategy. Empirically investigating its validity therefore holds considerable potential. However, such an investigation is demanding. It requires data on termination preferences and on varying degrees of termination uncertainty. But the Norwegian amalgamation reform offers precisely such data. As elaborated next, this reform allows us to study what comparable agencies having known preferences do when faced with comparable termination threats but of varying certainty. The hypothesis on certainty can be tested by comparing observations in cells $\mathrm{A}, \mathrm{B}$, and $\mathrm{C}$ (and by comparing D, E, and F). As described below, we have observations in A, B, and C. The hypothesis on preferences can be tested by comparing cells A and D, B and E, and C and F. We have observations in cells B and E.

\section{Research Setting}

Norwegian local governments are multipurpose jurisdictions having a comparatively high level of local autonomy (Ladner et al. 2016) and account for approximately $30 \%$ of all public spending in Norway. Their main sources of revenue are grants from the national government (about 45\%), taxation (about 35\%), and service charges (about 13\%). Income tax rates are decided by the national parliament and property tax rates by the local governments themselves. Generally, local governments can borrow money without approbation by the state (The Local Government Act defines legal borrowing purposes in $\S 50$ and circumstances where state approbation is required in $\S 60$ ). Local governments have fiscal autonomy to decide current spending and capital investment levels and the allocation of resources across 
policy areas, and elected councils decide what to do with funds not spent in a given year; they also have responsibility for deciding how to handle overspending relative to annual budgets (Baldersheim and Rose 2011; Ministry of Local Govermment and Modernisation 2018).

In 2014, Norway had 428 local governments, a number virtually unchanged since the mid-1960s. Only Parliament can instruct local governments to amalgamate. In 1995, Parliament decided that in principle, municipal mergers would be voluntary. Between 1995 and 2013, few mergers occurred, all based on local applications to merge. After the fall 2013 parliamentary election, the Conservative Party and the Progress Party formed a minority coalition government that had local government reform high on its political agenda. The reform was formally launched in April 2014, with the government's presentation of the reform to Parliament. The government aimed to reduce the number of local governments and to boost the quality of service delivery, expand the territorial scope for planning, ensure correct exertion of legal authority, and allow reduced central government supervision. Improved cost efficiency and allocative effectiveness were emphasized in a report the government commissioned from a committee of experts, but not in the government's own presentation of the reform (Ministry of Local Government and Modernisation 2014b, 2014c; Hansen 2016; Klausen et al. 2016).

The parliamentary majority decided that voluntariness would be the guiding principle but that force could be applied in "a few" cases "where individual local governments must be prevented from blocking changes that are necessary in light of regional considerations" (Norwegian Parliament 2014, 41-2; this and similar passages are the authors' own translations). Alongside this threat of forced amalgamation, the main reform instruments were economic carrots, in the form of subsidies for amalgamation, and sticks, in the form of a change to the municipal finance system (effective from 2017): "Voluntarily small" municipalities would get reduced base grants while grants would remain unchanged for larger 
municipalities and for small ones that, based on their large distance from the nearest urban area, are "involuntarily small" (Klausen et al. 2016).

The government expected that "[municipal] debts might increase because the present municipal council could invest and roll the costs onto the new, larger municipality" (Ministry of Local Government and Modernisation 2014c, 50). The government therefore prepared a bill on state regulation of loans and long-term rental agreements for all municipalities in 2015, 2016, and 2017. The proposed bill was subjected to a public consultation in May and June 2014. The proposal underlined the need to "prevent purely strategic adaptations in anticipation of the local government reform" and to prevent that local decisions on "loans, investments, and localization [of new buildings] create disagreement among municipalities that are candidates for amalgamating" (Ministry of Local Government and Modernisation 2014a, 3). The proposed bill was criticized by opposition parties in Parliament (on the grounds that municipalities should be trusted to act responsibly) and by 140 municipalities during the consultation process. To reduce controversy over the reform, the government shelved the bill, adopted a more modest policy by establishing inter-municipal amalgamation boards having certain regulatory functions (Ministry of Local Government and Modernisation 2017, 42-3), and stated that municipalities had "communicated ... that they will take responsibility for making sure that loans and investments are considered with a view to the future local government structure" (Ministry of Local Government and Modernisation 2014d, $137-8)$.

From August 2014, municipalities were instructed to evaluate the prospects of amalgamating with neighbors of their choice and encouraged to enter into intent-to-merge contracts with others, to hold an advisory referendum or undertake other activities to allow citizens a say, and, by July 2016, to state, by council decision, the municipality's preference: merge or not. In the process, 153 intent-to-merge contracts were made, involving more than 
300 municipalities; 219 municipalities held a local referendum, and 155 decided they wanted to amalgamate. Some did and others did not specify with whom they were willing to amalgamate. $^{3}$

Norway's 19 county governors were tasked with guiding and, if necessary, pushing municipalities through this process from August 2014 onwards (Klausen et al. 2016). County governors submitted their recommendations to the Ministry of Local Government and Modernisation in October 2016 about which mergers to implement. Although this was a cruical event, it is fair to say that the level of territorial uncertainty decreased gradually between 2014 and 2016. The national government released its design principles for a new municipal structure in spring 2014 (Ministry of Local Government and Modernisation 2014b) and, moreover, most county governors involved municipalities in an interactive process that involved frequent meetings, transparency about evaluative criteria, and even in some cases, airing preliminary conclusions (Foss 2016; Glomsrud 2017). Uncertainty was further reduced in April 2017, when the government presented its reform bill to Parliament (there was no guarantee that county governors' recommendations would be followed), and in June 2017, when Parliament voted on the bill (a minority government was in power). For most municipalities, the county governor's recommendation accorded with local decision to amalgamate or not to amalgamate. However, for 56 municipalities, county governors recommended amalgamation, contrary to local decisions not to amalgamate. Few expected the upcoming bill to propose mergers involving municipalities whose decisions not to amalgamate had been approved by their county governors. For this group, numbering 217 municipalities, territorial uncertainty was therefore nearly fully relaxed after October 2016.

\footnotetext{
${ }^{3}$ Details on intent-to-merge contracts and local referenda were collected from the webpage of The Centre of Competence on Rural Development, a state agency under the Ministry of Local Government and Modernisation.
} 


\section{Research Design, Data, and Methods}

To measure the treatment variables - uncertainty and merger preferences - we use a unique data set based on document analysis of municipalities' intent-to-merge contracts, county governors' recommendations to the Ministry of Local Government and Modernisation, and municipalities' councils' decisions about whether to be open to merger or not. The variation in uncertainty springs from actions and recommendations of the Ministry and county governors. Regarding preferences, municipalities can state their desire to be amalgamated or not. Their wishes can be rejected or approved by upper-level government. As a result of this process, municipalities might end up in one of four categories: certain and voluntary amalgamation (corresponding to group A in Table 1), potential voluntary amalgamation (group B in Table 1), potential forced amalgamation (group E) or certain and voluntary nonamalgamation (group C). We have no cases of category D and F, since no amalgamations were known for certain to have been forced and no forced amalgamations were known to have failed at the time of study. Table 2 presents a classification of the 428 Norwegian municipalities at the end of 2016 and the characteristics of the four categories of municipalities.

(Table 2 about here)

We use the assignment of municipalities to the four groups to estimate the effects on hoarding of territorial uncertainty and merger preferences. The reform process in 2014 induced territorial certainty for all municipalities - but to varying degrees. We apply a difference-indifference (DiD) logic and compare municipal spending before and after the reform process began across municipalities in these four categories, testing whether municipalities experiencing higher levels of territorial uncertainty changed economic policy relative to municipalities facing lower levels of territorial uncertainty. We do this testing by comparing groups A and B with the group of non-amalgamating municipalities (group C). In addition, 
we expect hoarding to occur to a higher degree in municipalities facing a potential forced amalgamation than in municipalities facing a potential voluntary amalgamation. Accordingly, we expect hoarding to occur to a higher degree in group E than in group B. Since we cannot completely rule out that non-amalgamating municipalities $(\mathrm{C})$ could have been subject to some level of territorial uncertainty $(\mathrm{p}>0)$ and are therefore not a clean control group of "no treatment," our design represents a conservative test of whether hoarding levels vary with different levels of territorial uncertainty.

Recall from the introduction that hoarding is understood as municipal spending beyond that which would otherwise be the case, greater spending driven by the expectation that municipalities can keep benefits for their present citizenry while sharing costs with others in the amalgamated entity. One obvious measure of spending is current expenditures, measured as the net operating result per capita (current revenues less current expenditures and interest). This is a standard indicator for the overall current fiscal balance of a municipality (Hansen et al. 2014). The net operating result will decrease the more aggressively a municipality spends on, for example, current services relative to its income. A second measure of spending that is relevant in the context of municipal amalgamations is capital expenditures (see e.g., Blom-Hansen 2010; Jordahl and Liang 2010; Saarimaa and Tukiainen 2015). In practice, we measure capital expenditures as gross investments per capita; this captures potential hoarding of capital goods like building new roads, sport arenas, or institutions for children or the elderly. In an amalgamation context, politicians might, on the one hand, have more incentives for hoarding capital goods than for increasing current spending, because capital goods represent visible long-term goods for the citizenry. Capital expenditures, on the other hand, require more planning and time to be implemented and are thus a less flexible and feasible policy instrument for hoarding than current expenditures. 
To measure these two dependent variables, we use 2012-2016 data from the official Norwegian database for municipal accounting (Statistics Norway 2018). Our data thus cover two years before the reform process was initiated (2012 and 2013), two years of voluntary local processes of evaluating the rationale of merging (2014 and 2015), and one year in which the group of potential forced amalgamations in the last three months of the year had strong reason to expect forced amalgamation (2016). ${ }^{4}$ The year 2017 is not included because the situation shifts halfway through that year, with Parliament's passing of the reform bill, from one of uncertainty to one of certainty over whether a merger will occur or not.

Municipal economic policies are influenced by other factors than territorial uncertainty and potential amalgamation, and since assigning municipalities to the four groups is not random, we include standard control variables known from previous analyses of economic policies of Norwegian municipalities (Hagen and Vabo 2005; Borge et al. 2008). First, we include an indicator for municipal expenditure needs based on the criteria in the Norwegian Equalization Scheme on the age and socioeconomic composition of the population. Second, an indicator of municipal wealth controls for variations in economic potential among municipalities. Third, because economic policies might be subject to economies of scale, we control for differences in the overall size of the population. Appendix Table A1 provides descriptive statistics on all variables. In addition, Appendix Table A2 breaks this information down by the four categories of municipalities.

Since our data have a panel structure, OLS regression might produce biased results because of autocorrelation and heteroscedasticity. We therefore run OLS regressions with cluster-corrected standard errors (clustered at the level of the individual municipality).

\footnotetext{
${ }^{4}$ We exclude the municipality of Oslo because of its two-tier status as both county and municipality. In addition, we exclude an extraordinarily small island municipality (Utsira) and 10 municipalities that are incomparably rich because of revenues from large hydropower plants. The data set thus contains 416 cases across five years, a total of 2,080 observations. As data for one municipality merged in 2012 is missing for 2012, the final data set consist of 2,079 observations.
} 


\section{Results}

Before turning to the DiD-based regression analyses, we present a first view of the dependent variables in Figure 2, which compares the development over time in the four groups of municipalities. It is important for the validity of the DiD analyses presented below that the different groups were evolving along similar paths before the "treatment" of territorial uncertainty. Overall, Figure 2 does not indicate systematically different trends across the four groups before the reform process was initiated in 2014. However, pre-reform trends for group A (voluntary amalgamations) for net operating results and for group E (potential forced amalgamations) for gross investments are less similar to the others, so results for these groups are indicative. However, to increase the overall robustness of regressions and to make estimates less sensitive to yearly fluctuations, we use the average of the two pre-reform years 2012 and 2013 as the basis for DiD estimates.

(Figure 2 about here)

Figure 2 shows that the average net operating result declines in 2014 for all four groups of municipalities. This decline indicates that initiating the reform process in 2014 induced territorial uncertainty in all municipalities. However, the main point of interest is whether relative changes from pre-reform years to post-reform years were larger among municipalities voluntarily amalgamating, potentially voluntarily amalgamating, or being potentially forcedly amalgamated than among municipalities not going to amalgamate. This aspect of the changes is formally tested in Table 3, which presents the DiD-based regression analyses.

(Table 3 about here)

The first three parameters in Table 3 are a set of dummies for territorial uncertainty and merger preferences, estimating the pre-reform difference between each of three groups and the control group of municipalities not facing an amalgamation (i.e., the difference between 
the groups in the last two years before the reform process was initiated). None of these estimates are significant, indicating that when controlling for population size, wealth per capita, and expenditure needs, no significant pre-reform difference existed between the three treatment groups and the control group regarding the level of net operating results and gross investments.

In line with the DiD logic used in Blom-Hansen et al. (2016), the second block of variables uses DiD estimates to test whether the difference between the levels of operating results and gross investments in non-amalgamating municipalities and the three treatment groups is affected by the initiation of the reform process in 2014. The DiD estimates are interaction terms interacting the group the municipality belongs to with each post-reform year. For all parameters, the reference category for the estimation is the level in 2012-2013 for the control group of non-amalgamating municipalities. For each post-reform year, each estimate thus tests whether the difference between the specific group and the group of nonamalgamating municipalities is larger or smaller than it was in the pre-reform years 20122013.

We test the effects of uncertainty by comparing municipalities in groups $\mathrm{A}, \mathrm{B}$, and $\mathrm{C}$, using $\mathrm{C}$ as the reference category. The first $\mathrm{DiD}$ estimate for the net operating result (model 1) shows that the difference between the group of certain voluntary amalgamation (group A) and the non-amalgamating municipalities (group C) decreased by NOK 267 per capita from 2012/2013 to 2014 . The negative coefficient implies that municipalities certain to amalgamate increased current expenditures relative to income more aggressively from 2012/2013 to 2014 than did non-amalgamating municipalities. The change is not statistically significant in 2014 . In 2015 and 2016, however, when local amalgamation processes progressed, the group of voluntary amalgamation reduces the net operating result significantly relative to the nonamalgamating municipalities, compared to the pre-reform situation in 2012/2013. Compared 
to the average net operating result of NOK 2,257 per capita for all municipalities in the years studied, the size of the reduction (NOK 1,270-1,450) also represents a substantially significant reduction. Measured by the net operating result, voluntarily amalgamating municipalities are hoarding. Hoarding is however not reflected in increased capital investments, at least not by the end of 2016.

Turning to group B (potential voluntary amalgamations), we see that hoarding in these municipalities is less pronounced and is not significantly reflected in either of the two dependent variables. Hoarding is thus higher among municipalities certain to face amalgamation in 2017 or 2018 than among more hesitant ones, that is, municipalities that volunteered to amalgamate but only at a later stage and that did not necessarily find a specific partner. Hence as expected, we observe that greater certainty of amalgamation leads to increased hoarding, with statistically significant differences between the certain and voluntary amalgamations compared with the voluntary and certain non-amalgamations. The fact that only limited hoarding occurs among the potentially voluntarily amalgamating municipalities does not rule out that hoarding for these municipalities will increase in the future, because the actual or potential amalgamations for these municipalities are not until 2020.

Finally, turning to the group of potential forced amalgamation (group E), Table 3 shows that these municipalities might have anticipated a threat of amalgamation quite early in the reform process. Even though county governors did not submit their recommendations to Parliament until October 2016, their assessments were initiated in 2014, and results in Table 3 indicate that the group of potential forced amalgamations might have anticipated a threat of forced amalgamation because these municipalities in 2014 and 2015 significantly reduced their net operating result relative to the non-amalgamating municipalities in group C. An additional analysis (not shown) confirms our expectations, that hoarding will be higher for forced than for potential voluntary amalgamations. In both 2014 and 2015, the drop in net 
operating results in the group of potential forced amalgamations (group E) was significantly larger than it was in the group of potential voluntary amalgamations (group B). This difference is consistent with the expectation that preferences for amalgamations matter for hoarding. None of the DiD estimates for the group of potential forced amalgamations are significant in 2016. Hoarding thus seems less pronounced in the year when it seemed certain that forced amalgamation would be recommended, 2016, than in the preceding years when the threat of amalgamation was anticipated. This finding indicates that the period of certainty from October to December 2016 - might have been too short for any particular "protest" hoarding to be reflected in municipal accounts for the entire year 2016. It is also possible that recommendations were anticipated at an early stage.

The lower part of Table 3 contains control variables and year dummies. Controls for municipal wealth, expenditure needs, and population size generally have expected signs, indicating that variations in economic policies across municipalities and over time depend on these demographic and socioeconomic contingencies in the period studied. Net operating results and gross investments seem higher in wealthier municipalities. In addition, gross investments per capita are significantly lower the larger the population size.

The year dummies estimate the general time trend in the period (with 2012/2013 as reference), that is, the development in economic policies in the control group.

To test the robustness of the results, all models have first been run without control variables, then with outliers excluded (based on Cook's D), and finally with fixed effects. These robustness tests are shown in Appendix Table A3. As is evident, they produce substantially the same results as shown in Table $3 .^{5}$

\footnotetext{
${ }^{5}$ The parameter estimates are generally of similar size across models. The only notable difference can be found in the fixed-effects model, where the effect for "Potential forced" is statistically significant in the last year, while the effect for "Voluntary amalgamation" is not statistically significant in the last two years.
} 


\section{Discussion and Conclusion}

Kaufman's (1976) original discussion of agency mortality and Carpenter and Lewis's (2004) call for studies of agency strategy have inspired our attempt to move agency termination research beyond antecedents of termination and to study what agencies do when their future existence is doubtful. Unlike most scholarship in the organization ecology tradition of Hannan and Freeman (1977; see also van Witteloostuijn and Péli 2008) and in the corporate takeover/shark-repellent tradition of Stein (1988), we have not studied what organizations do to fend off termination threats. We have focused instead on what internal forces are unleashed in government agencies in the period between the decision phase and actual implementation of the termination. We develop, building upon the common pool problem, a game theoretic model of agencies facing termination. In general terms, we expect that agencies do have incentives for short-term strategic positioning in this situation. We find clear empirical evidence that agencies are affected dramatically by an anticipated threat of termination. They change policies in ways that can be understood by reflecting on incentives they face. Leaders of agencies are dedicated not only to their agencies but also to their agencies' constituencies, or more specifically, to policies that constituencies such as clients, beneficiary groups, and employees care about (Wilson 1989, 119). If avoiding termination is unrealistic, leaders might take last-minute steps to avoid that agency termination leads to abolishing policies important to constituencies (Bardach 1976, 124). Given the changed environmental circumstance - the threat of termination - altering policies might in fact be consistent and thus entirely legitimate, seen from the perspective of the agency's core constituency (Boin et al. 2017, $666-7)$.

As demonstrated in this study of municipalities, leaders protective of the interests of their agencies' constituents can, for example, unleash a flurry of spending activity once a credible threat to their agencies' existence is detected. As held by many organizational 
ecologists, municipalities might well be insufficiently "rational, flexible and speedy" to adapt in "meaningful" ways to prevent termination (Freeman and Hannan 1989, 426; Boin et al. 2017, 666). Still, they are sufficiently rational, flexible, and speedy to take advantage of the environmental disturbance to hoard resources for their citizens and territory. The study furthermore shows that termination need not be a certainty for government agencies to begin spending resources beyond what they would do absent an existential threat. However, the level of such opportunistic behavior increases as the perceived likelihood of extinction increases.

Large-N studies, such as ours, rely on theory rather than on evidence to pinpoint the social mechanisms that explain hoarding. To substantiate our interpretations, we can refer to one of the very few case studies in the literature. Three Norwegian municipalities that will merge into one in 2020 all started to increase investments in healthcare, education, and sports facilities before a merger was even remotely a certainty. They understood that increasing investments was a gamble, since the merger might not materialize, but they were driven by a desire to prevent future centralization of service infrastructure (thus supporting BlomHansen's argument (2010)). Furthermore, hoarding increased when the municipalities became more certain that a merger would happen, partly because of contingencies built into investment decisions made under lower certainty (e.g., "cancel if the merger does not materialize"). Finally, the case study shows that depleting their future common pool can be something organizations like municipalities agree to do, at least up to a level agreed by all; it is not necessarily something they try to hide from each other (Bråstein 2018).

By focusing on municipalities facing amalgamation, we can study a large number of comparable organizations facing termination. This focus allows us to address the dual methodological problem of rare events and conceptual stretching associated with studying agency terminations. We believe that this focus lends credibility to the internal validity of the 
results. However, it raises a question of generalizability: Are findings from a study of municipalities valid for our general understanding of agency strategies in existentially threatened government agencies? Municipalities are distinguished from many other agencies by their locally elected governance boards and strong ties to the local population. We would therefore hesitate to argue that managers of other types of agencies would likely react in the exact same way to termination threats, that is, by hoarding. However, we think that the broader point that local decision makers actively react to termination threats and act strategically to benefit citizens, clients, beneficiary groups, and/or employees is likely to hold for other types of agencies.

Theoretically, we developed a game theoretical argument that links termination certainty and termination preference to agency policy. The empirical evidence allowed for only partial tests of the deduced hypotheses. The results indicate, though, that further development and testing of game theoretic arguments is a promising avenue for understanding termination-threatened agencies' short-term strategic behavior and, more generally, for coupling this relatively unexplored phenomenon to common-pool-problem scholarship (Choi and Robertson 2018).

The results also have practical implications for amalgamation reforms. When amalgamations are seen from the perspective of strategic behavior under termination hazard, it becomes clear that such reforms strongly incentivize increased spending. This type of economic policy can begin almost as soon as the possibility of termination is aired. Unless addressed by countermeasures, these incentives might lead to collectively perverse results and undermine the very reasons for reform, at least in the short run. The reform under study here is, to some extent, a case in point. Municipalities started to hoard once the government said the word "amalgamation," thus reducing any hopes the government - or taxpayers - might have harbored for improved cost and allocative effectiveness as a result of the reform under 
consideration. Usually, we think public sector reorganization can end up being very expensive because of the necessity of buying off certain stakeholders. This article gives us another reason: reorganization can lead to expensive last-minute spending.

We highlight three takeaways for potential reformers. First, the results show that territorial uncertainty can be sufficient to make municipalities hoard; amalgamation need not be even remotely a certainty. A benefit of studying the earliest stage of a reform, where the merger decision is unknown and, therefore, no work has begun on establishing the new entity, is that we can be fairly confident that effects we observe do reflect opportunism, which is the social mechanism in the law of $1 / \mathrm{n}$, and not "theoretically irrelevant" phenomena such as transitory costs relating to reorganization and harmonization of service levels (Hansen 2014; Jordahl and Liang 2010). The finding that Norwegian municipalities increased spending at the earliest stage of reform is remarkable because the incentive to spend is relatively small until it is certain or highly likely that amalgamation will occur (Hansen 2014, 19). Usually, there is uncertainty over such matters up until the late stages of a reform. Our interpretation is that many municipalities are willing to gamble. Even talk about amalgamation reform can spark increased spending. Therefore, Jordahl and Liang $(2010,162)$ were right to expect that freeriding might begin once municipalities anticipate a reform, and in the Norwegian case, the absence of state regulation of local economic policy allowed municipalities to act on this incentive, contrary to what occurred in relatively recent reforms in, for example, Denmark (Blom-Hansen 2010) and Japan (Nakazawa 2016). Perhaps the government's failed attempt to limit overspending during the first year of the reform had the opposite effect: Local governments thought they had to overspend immediately, before a ban was installed. If so, that is a note of caution for future reformers: Saying that a ban is needed is like setting up a "No U-turn" sign: It shows that something (i.e., overspending in this case) is possible. Therefore, the lesson is that unless or until governments are sure they have enough political 
leverage to install a regulation that can limit negative effects of certain incentives, it is best not to bring attention to these incentives.

Second, the results show that variance in the perceived likelihood of a merger influences hoarding levels. As expected, we found a positive association between the two. Spending was higher among municipalities for whom amalgamation was a real possibility (the potentially voluntarily amalgamating municipalities) than among those for whom amalgamation was highly unlikely. For the fast-tracked municipalities, spending was higher toward the end of the reform process. In other words, although spending generally increases when amalgamation reform is on the table, effects vary predictably, with the strongest effects for those most likely to be affected.

Third, it is noteworthy that increased spending takes place not only in municipalities forced into amalgamations (our group E), but also in some cases in municipalities entering into amalgamations voluntarily (our group A). Studies of this question have shown mixed results. Fritz and Feld (2015) find weaker effects for volunteers in German data, while Saarimaa and Tukiainen (2015) observe a stronger effect in the context of voluntary mergers in Finland. Saarimaa and Tukiainen $(2015,141)$ argue that this is somewhat surprising since municipalities that have agreed to merge should also be able to agree not to exploit the common pool. However, we can speculate that municipalities that have agreed to merge can also, formally or informally, agree to exploit the common pool, up to a level accepted by all.

The substantive size of the overspending and the time horizon are of course important for the net cost-benefit evaluation. It can be that (very) long-term positive effects of a termination, whether of the merger type or of a different type, outweigh short-term costs. It might also matter what overspending is used for, since some projects might make more sense than others to the newly merged municipality. This case has offered an illustration: The Norwegian government expected increased spending and planned to restrict it through 
regulation but chose not to when faced with resistance from municipalities and opposition parties in Parliament. Having municipalities amalgamate voluntarily was the top priority; local "excesses" was a price the government was willing to pay for expected benefits in future decades. 


\section{References}

Adam, Christian, Michael W. Bauer, Christoph Knill, and Philipp Studinger. 2007. "The Termination of Public Organizations: Theoretical Perspectives to Revitalize a Promising Research Area." Public Organization Review 7(3): 221-36.

Baldersheim, Harald, and Lawrence E. Rose. 2011. "Norway: The decline of subnational democracy?” In Frank Hendriks, Anders Lidström, and John Loughlin (eds), The Oxford Handbook of Local and Regional Democracy in Europe. Oxford: Oxford University Press (pp. 282-304).

Bardach, Eugene. 1976. “Termination as a Political Process.” Policy Sciences 7(2): 123-31.

Blom-Hansen, Jens, Kurt Houlberg, Søren Serritzlew, and Daniel Treisman. 2016.

"Jurisdiction Size and Local Government Policy Expenditure: Assessing the Effect of Municipal Amalgamation.” American Political Science Review 110(4): 812-31.

Blom-Hansen, Jens. 2010. "Municipal Amalgamations and Common Pool Problems: The Danish Local Government Reform in 2007.” Scandinavian Political Studies 33(1): $51-73$.

Boin, Arjen, Celesta Kofman, Jeroen Kuilman, Sanneke Kuipers, and Arjen van Witteloostuijn. 2017. "Does organizational adaptation really matter? How mission change affects the survival of US federal independent agencies, 1933-2011.” Governance 30(4): 663-86.

Boin, Arjen, Sanneke Kuipers, and Marco Steenbergen. 2010. “The Life and Death of Public Organizations: A Question of Institutional Design?” Governance 23(3): 385-410.

Borge, Lars-Erik, Torberg Falch, and Per Tovmo. 2008. "Public Sector Efficiency: The Roles of Political and Budgetary Institutions, Fiscal Capacity, and Democratic Participation." Public Choice 136(3): 475-95. 
Bråstein, Mari R. 2018. Nå eller aldri En casestudie av фkonomiske disposisjoner i forkant av kommunesammenslåing [Now or never. A case study of economic dispositions before municipal amalgamation]. Master's thesis. Oslo: Department of Political Science, University of Oslo.

Carpenter, Daniel P., and David E. Lewis. 2004. "Political Learning from Rare Events: Poisson Inference, Fiscal Constraints, and the Lifetime of Bureaus.” Political Analysis 12: $201-32$.

Choi, Taehyon and Peter J Robertson. 2018. "Contributors and Free-Riders in Collaborative Governance: A Computational Exploration of Social Motivation and Its Effects.” Journal of Public Administration Research and Theory. https://doi.org/10.1093/jopart/muy068

Dommett, Katharine, and Chris Skelcher. 2014. "Opening the Black Box of Administrative Reform: A Strategic-Relational Analysis of Agency Responses to Termination Threats." International Public Management Journal 17(4): 540-63.

Downs, Anthony. 1967. Inside Bureaucracy. Lexington, MA: Lexington Books.

Foss, Anniken G. 2016. “Fylkesmannens rolle i kommunereformen. En casestudie av Østfold og Vestfold.” In Jan Erling Klausen, Jostein Askim, and Signy Irene Vabo (eds), Kommunereform i perspektiv. Bergen: Fagbokforlaget (pp. 70-85).

Freeman, John and Michael T. Hannan. 1989. "Setting the Record Straight on Organizational Ecology: Rebuttal to Young.” American Journal of Sociology 95(2): 425-39.

Fritz, Benedikt, and Lars Feld. 2015. "The Political Economy of Municipal Amalgamation Evidence of Common Pool Effects and Local Public Debt.” CESifo Working Paper Series No. 5676. 
Glomsrud, Hans Rasmus. 2017. “Byråkraten mellom barken og veden. Om kryssende forventninger til fylkesmannens tilråding i kommunereformen.” MA thesis. Oslo: Department of Political Science, University of Oslo.

Hagen, Terje P., and Signy Irene Vabo. 2005. "Political Characteristics, Institutional Procedures and Fiscal Performance: Panel Data Analyses of Norwegian Local Governments, 1991-1998." European Journal of Political Research 44(1): 43-64.

Hannan, Michael T. and John Freeman. 1977. "The Population Ecology of Organizations." American Journal of Sociology 82(5): 929-64.

Hansen, Sune Welling, Kurt Houlberg, and Lene Holm Pedersen. 2014. “Do Municipal Mergers Improve Fiscal Outcomes?” Scandinavian Political Studies 37(2): 196-214.

Hansen, Sune Welling. 2014. “Common Pool Size and Project Size: An Empirical Test on Expenditures Using Danish Municipal Mergers.” Public Choice 159(1): 3-21.

Hansen, Tore. 2016. "Kommuneinndelingen - fra lokale økonomiske klubber til statlige velferdsprodusenter.” In Jan Erling Klausen, Jostein Askim, and Signy Irene Vabo (eds), Kommunereform i perspektiv. Bergen: Fagbokforlaget (pp. 47-69).

Hardin, Garrett. 1968. "The Tragedy of the Commons.” Science 162(3859): 1243-48.

Hinnerich, Björn Tyrefors. 2009. "Do Merging Local Governments Free Ride on Their Counterparts when Facing Boundary Reform? Journal of Public Economics 93: 72128.

Hirota, Haruaki, and Hideo Yunoue. 2017. "Evaluation of the Fiscal Effect on Municipal Mergers: Quasi-Experimental Evidence from Japanese Municipal Data.” Regional Science and Urban Economics 66: 132-49.

James, Oliver, Nicolai Petrovsky, Alice Moseley, and George A. Boyne. 2015. "The Politics of Agency Death: Ministers and the Survival of Government Agencies in a Parliamentary System.” British Journal of Political Science 46: 763-84. 
Jordahl, Henrik, and Che-Yuan Liang. 2010. "Merged Municipalities, Higher Debt: On FreeRiding and the Common Pool Problem in Politics." Public Choice 143: 157-72. Kaufman, Herbert. 1976. Are Government Organizations Immortal? Washington, DC: The Brookings Institution.

King, Gary, Robert O. Keohane, and Sidney Verba. 1994. Designing Social Inquiry. Scientific Inference in Qualitative Research. Princeton, NJ: Princeton University Press. Klausen, Jan Erling, Jostein Askim, and Signy Irene Vabo. 2016. "Kommunereformen i Norge.” In Jan Erling Klausen, Jostein Askim, and Signy Irene Vabo (eds), Kommunereform i perspektiv. Bergen: Fagbokforlaget (pp. 25-46).

Kuipers, Sanneke, Kutsal Yesilkagit, and Brendan Carroll. 2018. "Coming to Terms with Termination of Public Organizations." Public Organization Review 18(2): 263-78.

Ladner, A., Keuffer, N., and Baldersheim, H. (2016). Measuring local autonomy in 39 countries (1990-2014). Regional \& Federal Studies, 26(3), 321-57.

Lewis, David E. 2002. “The Politics of Agency Termination: Confronting the Myth of Agency Immortality.” Journal of Politics 64(1): 89-107.

Lijphart, Arend. 1971. "Comparative Politics and the Comparative Method." American Political Science Review 65(3): 682-93.

Lowi, Thodore J. 1979. The End of Liberalism. The Second Republic of the United States. New York: W. W. Norton.

Maccarthaigh, Muiris. 2014. “Agency Termination in Ireland: Culls and Bonfires, or Life after Death?" Public Administration 92(4): 1017-37.

Ministry of Local Government and Modernisation. 2014a. Høyring av lovframlegg om statleg godkjenning av kommunale låneopptak og leigeavtalar før iverksetjing av kommunereforma (14.5.2014). Oslo: Ministry of Local Government and Modernisation. 
Ministry of Local Government and Modernisation. 2014b. Kommunereform. Meldingsdel i Prop. 95 S, 2013-2014. Kommuneproposisjonen 2015. Oslo: Ministry of Local Government and Modernisation.

Ministry of Local Government and Modernisation. 2014c. Prop. 95 S, 2013-2014.

Kommuneproposisjonen 2015. Oslo: Ministry of Local Government and Modernisation.

Ministry of Local Government and Modernisation. 2014d. Prop. 1 S, 2014-2015 (The 2015 State Budget). Oslo: Ministry of Local Government and Modernisation.

Ministry of Local Government and Modernisation. 2017. Rundskriv til lov av 15. juni 2001 nr. 70 om fastsetjing og endring av kommune- og fylkesgrenser (inndelingslova). $\mathrm{H}-$ 10/15. March 2017. Oslo: Ministry of Local Government and Modernisation.

Ministry of Local Government and Modernisation. 2018. Prop. 88 S 2017-2018. Kommuneproposisjonen 2019. Oslo: Ministry of Local Government and Modernisation.

Moldogaziev, Tima T., Tyler A Scott, and Robert A Greer. 2019. “Organizational Dissolutions in the Public Sector: An Empirical Analysis of Municipal Utility Water Districts." Journal of Public Administration Research and Theory. https://doi.org/10.1093/jopart/muy081

Nakazawa, Katsuyoshi. 2016. “Amalgamation, Free-Rider Behavior, and Regulation.” International Tax and Public Finance 23(5): 812-33.

Norwegian Parliament (2014). Innst. 300 S 2013-2014. Innstilling fra kommunal- og forvaltningskomiteen om kommuneproposisjonen 2015. Oslo: Stortinget.

Ostrom, Elinor. 1990. Governing the Commons. The Evolution of Institutions for Collective Action. Cambridge: Cambridge University Press. 
Peters, B. Guy, and Brian W. Hogwood. 1988. "The Death of Immortality: Births, Deaths and Metamorpheses in the US Federal Bureaucracy 1933-1982." American Review of Public Administration 18(2): 119-33.

Rolland, Vidar W., and Paul G. Roness. 2011. "Mapping Organizational Change in the State: Challenges and Classifications." International Journal of Public Administration 34(6): 399-409.

Saarimaa, Tuukka, and Janne Tukiainen. 2015. "Common Pool Problems in Voluntary Municipal Mergers.” European Journal of Political Economy 38(1): 140-52.

Sartori, Giovanni. 1970. "Concept Misformation in Comparative Politics.” American Political Science Review 64(4): 1033-53.

Statistics Norway. 2018. KOSTRA. https://www.ssb.no/offentlig-sektor/kostra (Accessed 31 May 2018).

Stein, Jeremy C. 1988. "Takeover Threats and Managerial Myopia.” Journal of Political Economy 96(1): 61-80.

van Witteloostuijn, Arjen and Gábor Péli. 2008. “Organizational Ecology.” In Stewart R. Clegg and James R. Mailey (eds), International encyclopedia of organization studies. London, UK: SAGE (pp. 1056-59).

van Witteloostuijn, Arjen, Arjen Boin, Clesta Kofman, Jeroen Kuilman, and Sanneke Kuipers. 2018. "Explaining the survival of public organizations: Applying density dependence theory to a population of US federal agencies.” Public Administration 96(4): 633-50. Verhoest, Koen, Sandra Van Thiel, Geert Bouckaert and Per Lægreid. 2012. "Introduction," pp. 3-18 in Koen Verhoest, Sandra Van Thiel, Geert Bouckaert and Per Lægreid. Government Agencies. Practices and Lessons from 30 Countries. Houndsmills: Palgrave. 
Weingast, Barry R., Kenneth A. Shepsle, and Christopher Johnsen. 1981. "The Political Economy of Benefits and Costs: A Neoclassical Approach to Distributive Politics.” The Journal of Political Economy 89: 642-64.

Wilson, James Q. 1989. Bureaucracy: What Government Agencies Do and Why They Do It. New York, NY: Basic Books. 
Figures, Boxes, Tables

Figure 1. Strategic form game of termination

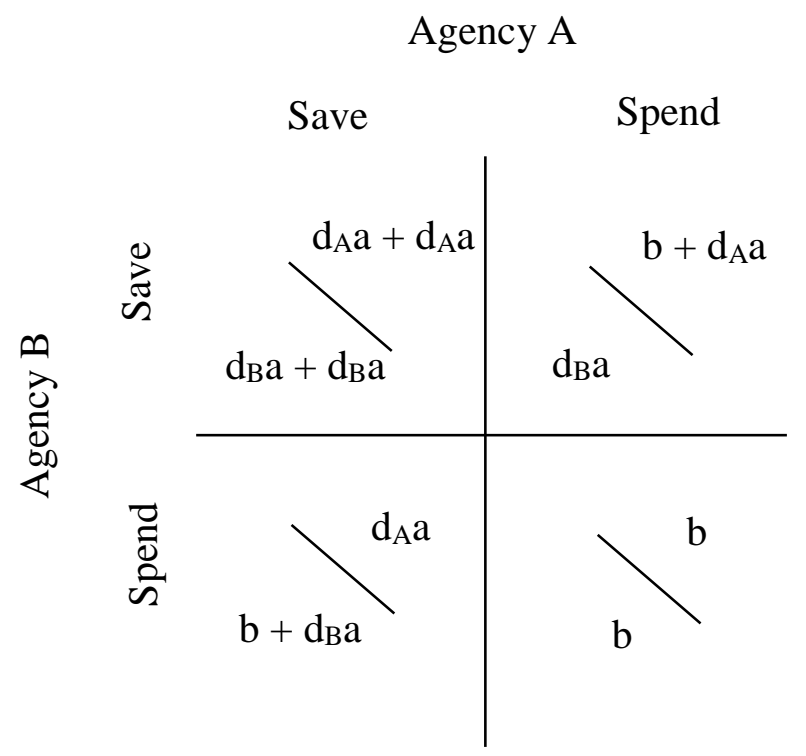


Figure 2. Group means for economic policies in the four groups of municipalities

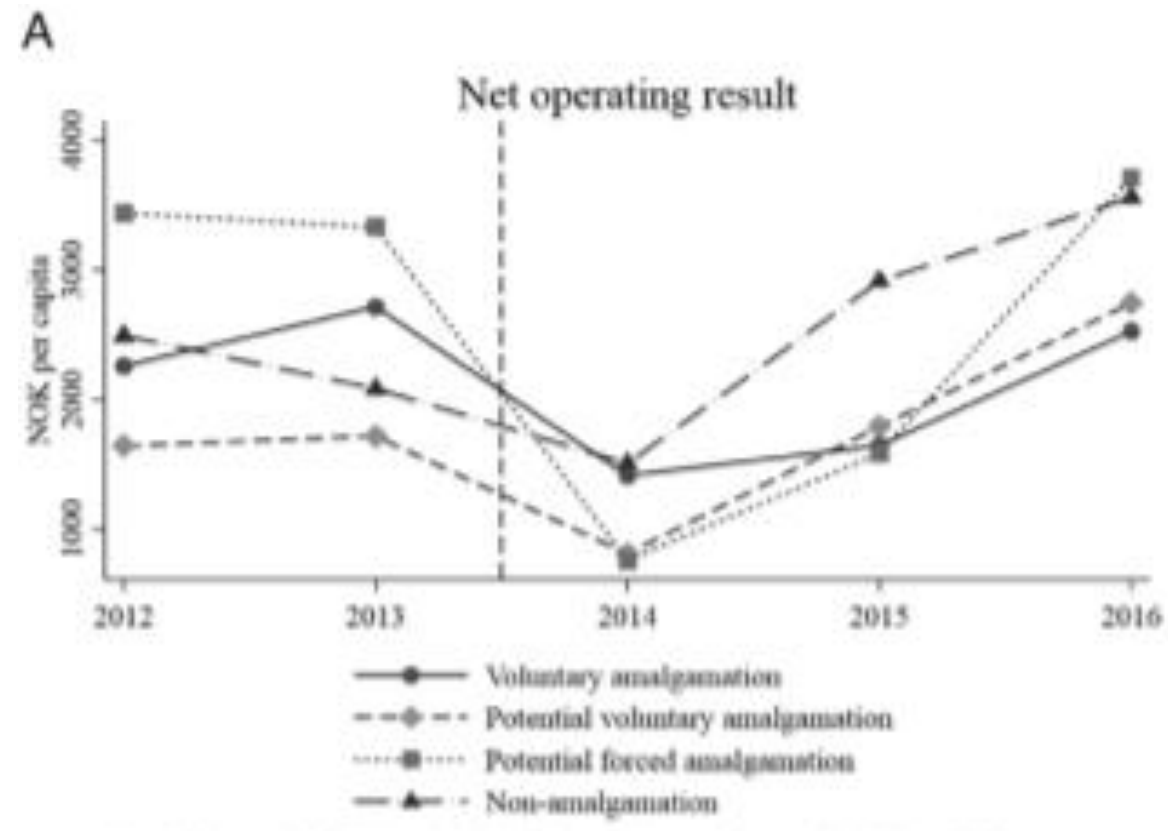

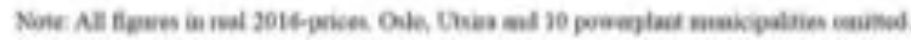

B

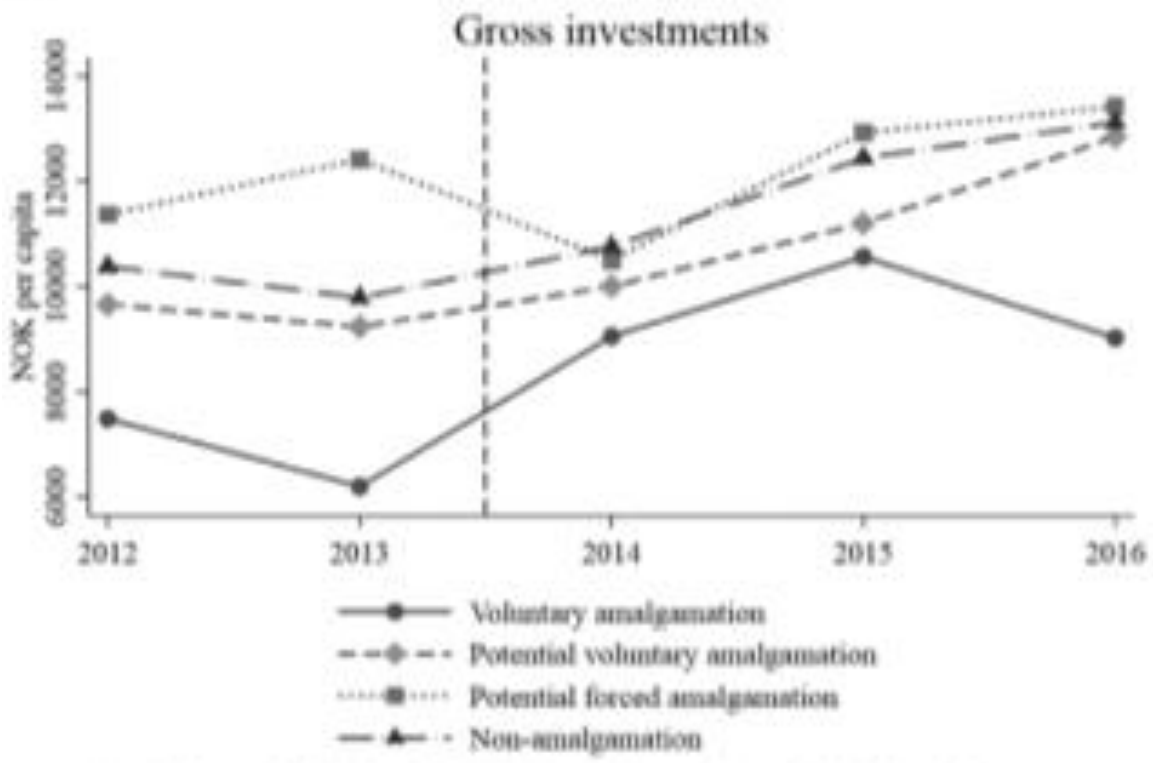

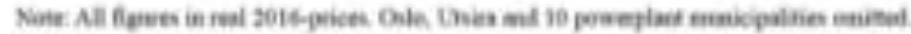

Figure 2. Group Means for Economic Policies in the Four Groups of Municipalities. 


\begin{tabular}{|c|c|}
\hline Study & Definition of agency termination \\
\hline $\begin{array}{l}\text { Kaufman } \\
(1976)\end{array}$ & $\begin{array}{l}\text { "As long as a boundary around a group of people included in the study was } \\
\text { uninterruptedly maintained, I treated them as an ongoing organization even } \\
\text { if the composition, activities, outputs, and inputs of the group did not } \\
\text { remain constant ... Of course, 'boundary' is not a simple, clear concept ... } \\
\text { Still, there are some reasonably concrete indicators of boundaries - for } \\
\text { example, visible symbols distinguishing an in-group from all others, rites of } \\
\text { boundary crossing ... perimeters of internal communications networks, } \\
\text { evidences of organizational jurisdiction (e.g., the distribution of the burdens } \\
\text { and benefits of membership)." (p. 28) }\end{array}$ \\
\hline Lewis (2002) & $\begin{array}{l}\text { "I consider an agency terminated if it has been eliminated whole with all of } \\
\text { its functions or if it has had a name change, location change, and change of } \\
\text { function." (p. 92). }\end{array}$ \\
\hline $\begin{array}{l}\text { James et al. } \\
(2015)\end{array}$ & $\begin{array}{l}\text { "We define the termination of a government agency as occurring when its } \\
\text { governance structure has been ended." (p. 770) }\end{array}$ \\
\hline $\begin{array}{l}\text { Maccarthaigh } \\
(2014)\end{array}$ & $\begin{array}{l}\text { "[Agency terminations are] deaths, mergers, absorptions, and } \\
\text { replacements." (p. 1028) }\end{array}$ \\
\hline $\begin{array}{l}\text { Boin et al. } \\
(2010)\end{array}$ & $\begin{array}{l}\text { "Organizations that were the result of a merger or that were split off from } \\
\text { existing organizations ... are here considered new ... We use the same } \\
\text { criteria to determine whether an organization has been terminated. A } \\
\text { merger of organizations or a split into two or more organizations counts as } \\
\text { a termination. When organizations are only changed in name and some of } \\
\text { their functions, they are not considered to be abolished." (pp. 390-1) }\end{array}$ \\
\hline
\end{tabular}


Box 2. Agencies included in selected studies

\begin{tabular}{|c|c|}
\hline Author & Agencies included in study \\
\hline $\begin{array}{l}\text { Kaufman } \\
(1976)\end{array}$ & $\begin{array}{l}421 \text { US federal agencies - "an exceedingly mixed group in size, function, } \\
\text { history, and budget" (p. 24) }\end{array}$ \\
\hline Lewis (2002) & $\begin{array}{l}426 \text { US federal agencies - "the data set includes cabinet departments, } \\
\text { administrations, bureaus, and large offices." (p. 104) }\end{array}$ \\
\hline $\begin{array}{l}\text { James et al. } \\
(2015)\end{array}$ & $\begin{array}{l}153 \text { UK executive ("next step") agencies including service-producing, } \\
\text { regulatory and research agencies (p. 770) }\end{array}$ \\
\hline $\begin{array}{l}\text { Maccarthaigh } \\
(2014)\end{array}$ & $\begin{array}{l}\text { Over } 700 \text { Irish national agencies - "a broad spectrum of organizations" ( } \mathrm{p} \text {. } \\
\text { 1019) ranging from executive agencies, over chartered corporations, to } \\
\text { private limited companies }\end{array}$ \\
\hline $\begin{array}{l}\text { Boin et al. } \\
(2010)\end{array}$ & $\begin{array}{l}63 \text { US federal organizations created between } 1933 \text { and } 1936 \text { ranging from } \\
\text { the Indian Arts and Crafts Board to the Rural Electrification Administration } \\
\text { (p. 409-10) }\end{array}$ \\
\hline
\end{tabular}


Table 1. Degree of hoarding

\begin{tabular}{|l|c|c|}
\hline & Voluntary & Forced \\
\hline $\begin{array}{l}\text { Certain amalgamation (extremely high } \\
\text { probability, } \mathrm{p}=1 \text { ) }\end{array}$ & A & D \\
\hline $\begin{array}{l}\text { Potential amalgamation (intermediate } \\
\text { probability, } 1>\mathrm{p}>0 \text { ) }\end{array}$ & B & E \\
\hline $\begin{array}{l}\text { Certain non-amalgamation (extremely low } \\
\text { probability, } \mathrm{p}=0 \text { ) }\end{array}$ & C & F \\
\hline
\end{tabular}


Table 2. Empirical classification of Norwegian municipalities with regard to preferences and territorial uncertainty at the end of 2016

\begin{tabular}{|c|c|c|c|}
\hline $\begin{array}{l}\text { Group of } \\
\text { municipalities }\end{array}$ & Characteristics & $\mathrm{N}$ & $\begin{array}{l}\text { Included in } \\
\text { multivariate } \\
\text { analysis }\end{array}$ \\
\hline $\begin{array}{l}\text { Certain and } \\
\text { voluntary } \\
\text { amalgamation } \\
\text { (type A) }\end{array}$ & $\begin{array}{l}\text { Municipalities that decided voluntarily at the } \\
\text { beginning of the reform process to amalgamate } \\
\text { and who had their mergers fast-track approved by } \\
\text { the Ministry of Local Government and } \\
\text { Modernisation. These mergers were/are } \\
\text { implemented in } 2017 \text { and } 2018 \text {, and the } \\
\text { municipalities will end up as voluntary } \\
\text { amalgamations. }\end{array}$ & 11 & 11 \\
\hline $\begin{array}{l}\text { Potential voluntary } \\
\text { amalgamation } \\
\text { (type B) }\end{array}$ & $\begin{array}{l}\text { Municipalities that decided voluntarily to } \\
\text { amalgamate but without necessarily having a } \\
\text { specific partner and, anyway, too late in the } \\
\text { reform process to be fast-tracked by the national } \\
\text { government. Eventually, these municipalities are } \\
\text { likely but not certain to end up as voluntary } \\
\text { amalgamations. }\end{array}$ & 144 & 144 \\
\hline $\begin{array}{l}\text { Potential forced } \\
\text { amalgamation } \\
\text { (type E) }\end{array}$ & $\begin{array}{l}\text { Municipalities that decided not to amalgamate } \\
\text { but for whom the county governor proposed a } \\
\text { forced amalgamation. These municipalities are } \\
\text { likely to be amalgamated against their will. }\end{array}$ & 62 & 62 \\
\hline $\begin{array}{l}\text { Certain and } \\
\text { voluntary non- } \\
\text { amalgamation } \\
\text { (type C) }\end{array}$ & $\begin{array}{l}\text { Municipalities whose decisions not to } \\
\text { amalgamate were approved by the county } \\
\text { governors. These municipalities will not be } \\
\text { amalgamated. }\end{array}$ & 211 & 211 \\
\hline \multicolumn{2}{|c|}{ Total number of municipalities } & 428 & 416 \\
\hline
\end{tabular}

Note: The category of potential forced amalgamation includes six municipalities for which the county governors did not make an explicit recommendation to Parliament for amalgamation but instead strongly encouraged these municipalities to find a merging partner before the end of 2016. Theoretically, these municipalities are in a position of territorial uncertainty comparable to that of the group of potential forced amalgamation and share the same risk of being forcedly merged by Parliament. 
Table 3. Regression analysis of hoarding and potential amalgamation 2012-2016

\begin{tabular}{|c|c|c|}
\hline & $\begin{array}{c}\text { (1) } \\
\text { Net operating } \\
\text { results }\end{array}$ & $\begin{array}{c}(2) \\
\text { Gross } \\
\text { investments }\end{array}$ \\
\hline \multicolumn{3}{|c|}{ Territorial uncertainty (ref. = Group C: non-amalgamation) } \\
\hline Group A: Certain and voluntary amalgamation & $\begin{array}{c}681.95 \\
(616.11)\end{array}$ & $\begin{array}{l}-1,612.21 \\
(1,458.77)\end{array}$ \\
\hline Group B: Potential voluntary amalgamation & $\begin{array}{l}-362.19 \\
(273.48)\end{array}$ & $\begin{array}{c}472.54 \\
(698.93)\end{array}$ \\
\hline Group E: Potential forced amalgamation & $\begin{array}{l}1,019.03 \\
(705.95)\end{array}$ & $\begin{array}{c}1,533.17 \\
(1,478.60)\end{array}$ \\
\hline \multicolumn{3}{|l|}{ DiD estimates } \\
\hline 2014* Group A & $\begin{array}{l}-266.55 \\
(583.68)\end{array}$ & $\begin{array}{c}1,610.67 \\
(1,153.98)\end{array}$ \\
\hline 2014* Group B & $\begin{array}{c}-68.64 \\
(301.50)\end{array}$ & $\begin{array}{c}-54.70 \\
(878.44)\end{array}$ \\
\hline 2014* Group E & $\begin{array}{c}-1,795.18 * * * \\
(612.59)\end{array}$ & $\begin{array}{l}-1,934.82 \\
(1,479.84)\end{array}$ \\
\hline 2015* Group A & $\begin{array}{c}-1,449.69 * * * \\
(483.62)\end{array}$ & $\begin{array}{c}1,398.81 \\
(3,278.60)\end{array}$ \\
\hline 2015* Group B & $\begin{array}{c}-511.40 \\
(370.69)\end{array}$ & $\begin{array}{c}-590.55 \\
(1,162.34)\end{array}$ \\
\hline 2015* Group E & $\begin{array}{c}-2,393.32 * * * \\
(672.67)\end{array}$ & $\begin{array}{c}-1,244.54 \\
(1,918.41)\end{array}$ \\
\hline 2016* Group A & $\begin{array}{c}-1,271.74 * * \\
(503.29)\end{array}$ & $\begin{array}{c}-986.27 \\
(2,145.25)\end{array}$ \\
\hline 2016* Group B & $\begin{array}{l}-221.10 \\
(313.11)\end{array}$ & $\begin{array}{c}335.13 \\
(1,427.84)\end{array}$ \\
\hline 2016* Group E & $\begin{array}{l}-924.07 \\
(595.78)\end{array}$ & $\begin{array}{l}-1,457.84 \\
(2,185.91)\end{array}$ \\
\hline \multicolumn{3}{|l|}{ Year dummies (ref. = 2012\&2013) } \\
\hline 2014 & $\begin{array}{c}-877.56 * * * \\
(245.55)\end{array}$ & $\begin{array}{c}401.58 \\
(638.64)\end{array}$ \\
\hline 2015 & $\begin{array}{l}550.81^{*} \\
(290.13)\end{array}$ & $\begin{array}{c}2,183.92 * * * \\
(819.51)\end{array}$ \\
\hline 2016 & $\begin{array}{c}1,170.46^{* * *} \\
(235.51)\end{array}$ & $\begin{array}{c}2,785.37 * * * \\
(878.78)\end{array}$ \\
\hline \multicolumn{3}{|l|}{ Control variables } \\
\hline Wealth per capita & $\begin{array}{c}0.09 * * \\
(0.04)\end{array}$ & $\begin{array}{c}0.25 * * \\
(0.11)\end{array}$ \\
\hline Expenditure needs per capita & $\begin{array}{l}-1,432.13 \\
(3,746.74)\end{array}$ & $\begin{array}{l}-10,398.77 \\
(8,437.69)\end{array}$ \\
\hline Population (ln) & $\begin{array}{c}181.71 \\
(218.48)\end{array}$ & $\begin{array}{c}-703.35^{*} \\
(392.12)\end{array}$ \\
\hline Constant & $\begin{array}{l}-2,995.02 \\
(4,172.29)\end{array}$ & $\begin{array}{l}12,668.58^{*} \\
(7,364.93)\end{array}$ \\
\hline Observations & 2,079 & 2,079 \\
\hline $\begin{array}{l}\text { Adj. } R^{2} \\
\max \text { VIF }\end{array}$ & $\begin{array}{l}0.083 \\
2.584\end{array}$ & $\begin{array}{l}0.062 \\
2.584\end{array}$ \\
\hline
\end{tabular}

Robust standard errors in parentheses (clustered at each municipality)

$* * * \mathrm{p}<0.01, * * \mathrm{p}<0.05, * \mathrm{p}<0.1$ 


\section{Appendix}

\section{Strategic form game of termination under uncertainty}

The game theoretic model in Figure 1 builds upon the assumption that termination is certain. We now relax this assumption. Let $\mathrm{p}$ indicate the probability that termination will happen.

Figure A1 illustrates the payoffs in that case. Now, the present value of saving is probabilistic. In case of no termination, the payoff is a; in case of termination, it is $d_{i} a$. With $p$ indicating the probability of termination, the expected payoff from saving is $(1-p) a+p d_{i} a$.

Figure A1. Strategic form game of termination under uncertainty

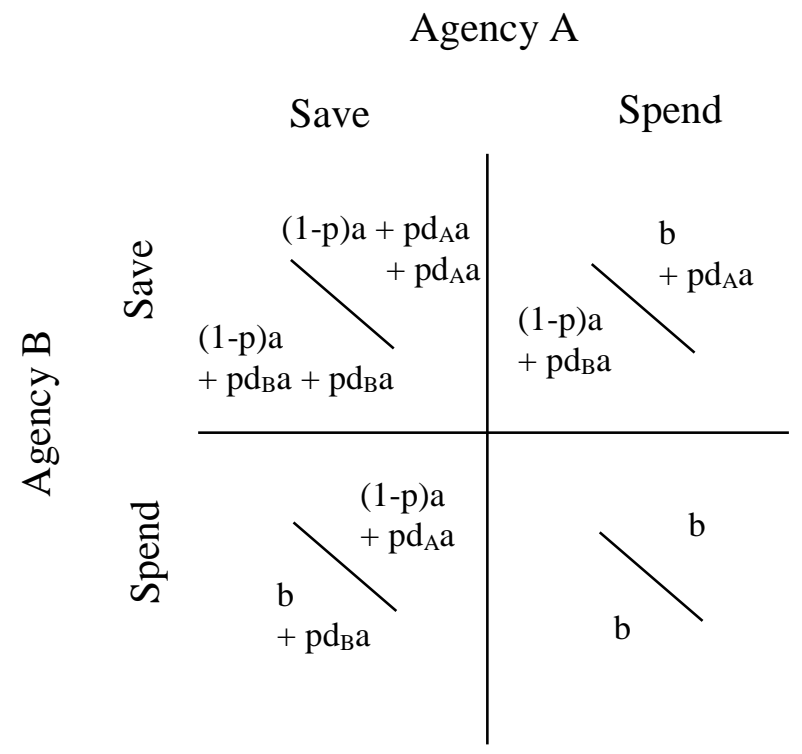

To solve the game, we first assume that $B$ saves. We then compare $M_{A}\left(S_{1}, s_{1}\right)$ with $M_{A}\left(S_{2}, s_{1}\right)$. A will spend if $\mathrm{M}_{\mathrm{A}}\left(\mathrm{S}_{2}, \mathrm{~s}_{1}\right)>\mathrm{M}_{\mathrm{A}}\left(\mathrm{S}_{1}, \mathrm{~s}_{1}\right) \Rightarrow \mathrm{b}+\mathrm{pd}_{\mathrm{A}} \mathrm{a}>(1-\mathrm{p}) \mathrm{a}+\mathrm{pd}_{\mathrm{A}} \mathrm{a}+\mathrm{pd}_{\mathrm{A}} \mathrm{a} \Rightarrow \mathrm{b}>(1-\mathrm{p}) \mathrm{a}+$ $\operatorname{pd}_{A}$ a. We then assume that $B$ spends. Comparing $M_{A}\left(S_{1}, s_{2}\right)$ with $M_{A}\left(S_{2}, s_{2}\right)$, we see that $A$ will spend if $\mathrm{M}_{\mathrm{A}}\left(\mathrm{S}_{2}, \mathrm{~s}_{2}\right)>\mathrm{M}_{\mathrm{A}}\left(\mathrm{S}_{1}, \mathrm{~s}_{2}\right) \Rightarrow \mathrm{b}>(1-\mathrm{p}) \mathrm{a}+\mathrm{pd}_{\mathrm{A}} \mathrm{a}$. In other words, $\mathrm{S} 2$ is a dominant strategy if $b>(1-p) a+p_{A} a$, and due to symmetry, $\left(S_{2}, s_{2}\right)-$ or Spend / Spend - is a Nash equilibrium under that condition. It also follows that spending is more likely for smaller agencies. If $d_{A}$ is small, $b>(1-p) a+p d_{A}$ a for even small values of $b$. In practical terms, the analysis shows that termination threats lead to hoarding, and that this tendency is stronger when the value of $p$ increases (since when $p$ increases, $(1-p) a+p d_{A}$ a decreases when $\left.d_{A}<1\right)$. Or, in other words, greater certainty about termination increases the likelihood of hoarding. 
Table A1. Measurement of variables

\begin{tabular}{|c|c|c|c|c|c|}
\hline VARIABLES & Measurement & Mean & Std. Dev. & Min & Max \\
\hline \multicolumn{6}{|l|}{ Main dependent } \\
\hline Net operating results & $\begin{array}{l}\text { Net operating results per capita in the final accounts of the year. } \\
\text { Net operating results is measured as current revenues less } \\
\text { current expenditures and interest ("Netto driftsresultat i kroner } \\
\text { per innbygger") }\end{array}$ & 2257 & 3477 & -9885 & 40042 \\
\hline Gross investments & $\begin{array}{l}\text { Gross capital expenditures per capita ("Bruttoinvesteringer per } \\
\text { innb.") }\end{array}$ & 11154 & 9319 & 218 & 106834 \\
\hline \multicolumn{6}{|l|}{ Main independent: } \\
\hline \multirow[t]{4}{*}{ Territorial uncertainty } & $\begin{array}{l}\text { Four categories of municipalities with regard to territorial } \\
\text { uncertainty. See text for further information } \\
\text { (ref. = non-amalgamation) }\end{array}$ & & & & \\
\hline & Voluntary amalgamation & 0.026 & 0.160 & 0 & 1 \\
\hline & Potential voluntary amalgamation & 0.339 & 0.473 & 0 & 1 \\
\hline & Potential forced amalgamation & 0.149 & 0.356 & 0 & 1 \\
\hline Control variables: & & & & & \\
\hline Wealth per capita & $\begin{array}{l}\text { Municipal wealth per capita. Total revenues from general grants } \\
\text { and local taxes ("Frie inntekter") Source: KOSTRA }\end{array}$ & 58973 & 10837 & 40649 & 104783 \\
\hline $\begin{array}{l}\text { Expenditure needs per } \\
\text { capita }\end{array}$ & $\begin{array}{l}\text { Demographic and socioeconomic needs per capita according to } \\
\text { the objective criteria in the Equalization Scheme. Measured as } \\
\text { an indicator measuring the within year position of the individual } \\
\text { municipality relative to a national average set at } 100 \text {. Due to } \\
\text { changes in the Equalization Scheme the indicator cannot be } \\
\text { compared across years and therefore measures the within year } \\
\text { position of the municipality relative to the national average. } \\
\text { Source: The Ministry of Local Government and Modernization, } \\
\text { yearly calculations for the Equalization Scheme } \\
\text { ("Inntektssystemet"). For } 2016 \text { see } \\
\text { www.regjeringen.no/contentassets/744de1ad6f0f4df09311c33ed } \\
\underline{\text { d01ae99/trykk gront-hefte.pdf. }}\end{array}$ & 1.21 & 0.14 & 0.90 & 1.75 \\
\hline Population (In) & $\begin{array}{l}\text { Natural log to municipal population January } 1^{\text {st. }} \text { Source: Statistics } \\
\text { Norway }\end{array}$ & 8.55 & 1.13 & 6.14 & 12.54 \\
\hline
\end{tabular}

$\mathrm{N}=2,079$ for all variables. All economic figures are based on final accounts and calculated in 2016 prices. All data are register data from the "KOSTRA" database run by Statistics Norway. (www.ssb.no/offentligsektor/kommune-stat-rapportering/kostra-databasen). They include data on municipal fiscal indicators stemming from the municipalities' accounting systems, based on national specifications set out by the national government framework for “KOSTRA”. In addition, Statistics Norway and the Ministry of Local Government and Modernisation collect demographic and socioeconomic data on all municipalities. 
Table A2. Descriptive statistics for the four groups of municipalities in regression models $(\mathrm{N}=416)$. Means for the pre-reform year, 2013.

\begin{tabular}{|c|c|c|c|c|c|}
\hline & $\begin{array}{l}\text { 1. Certain } \\
\text { and } \\
\text { voluntary } \\
\text { amalga- } \\
\text { mation }\end{array}$ & $\begin{array}{c}\text { 2. Potential } \\
\text { voluntary } \\
\text { amalga- } \\
\text { mation }\end{array}$ & $\begin{array}{l}\text { 3. Potential } \\
\text { forced } \\
\text { amalga- } \\
\text { mation }\end{array}$ & $\begin{array}{l}\text { 4. Certain } \\
\text { and } \\
\text { voluntary } \\
\text { non-amalga- } \\
\text { mation }\end{array}$ & $\begin{array}{c}\text { All } \\
\text { municipal- } \\
\text { lities }\end{array}$ \\
\hline \multicolumn{6}{|l|}{ Dependent variables: } \\
\hline Net operating result & 2715 & 1718 & 3329 & 2084 & 2162 \\
\hline Gross investments & 6198 & 9236 & 12430 & 9793 & 9902 \\
\hline \multicolumn{6}{|l|}{ Control variables: } \\
\hline Wealth per capita & 52055 & 55649 & 61123 & 60843 & 58892 \\
\hline Expenditure needs per capita & 1.04 & 1.08 & 1.13 & 1.14 & 1.12 \\
\hline Population (In) & 9.09 & 8.98 & 8.30 & 8.29 & 8.54 \\
\hline Population (not logged) & 14364 & 17650 & 6666 & 6932 & 10722 \\
\hline$N$ & 11 & 141 & 62 & 202 & 416 \\
\hline Share of municipalities (\%) & 2.6 & 33.9 & 14.9 & 48.6 & 100 \\
\hline
\end{tabular}

Note: Population (not logged) included in this table for illustrative purposes but not included in the regressions. 
Models without control Models excluding outliers

Fixed-effect Models variables

\begin{tabular}{ccccccc}
\hline Net & $(2)$ & $(3)$ & $(4)$ & (5) & (6) \\
$\begin{array}{c}\text { Gross } \\
\text { results }\end{array}$ & $\begin{array}{c}\text { Net } \\
\text { investments } \\
\text { operating } \\
\text { results }\end{array}$ & $\begin{array}{c}\text { Gross } \\
\text { investments }\end{array}$ & $\begin{array}{c}\text { Net } \\
\text { operating } \\
\text { results }\end{array}$ & $\begin{array}{c}\text { Gross } \\
\text { investments }\end{array}$
\end{tabular}

Territorial uncertainty (ref. $=$

Group C: non-amalgamation

Group A: Certain and voluntary amalgamation

$\begin{array}{cccc}197.71 & -3,248.92^{* * *} & 447.62 & -2,685.96 * * * \\ (585.00) & (1,368.31) & (470.48) & (884.57) \\ -607.90^{* * *} & -640.85 & -186.14 & 59.68 \\ (268.18) & (692.67) & (236.42) & (574.37) \\ 1,093.87 & 1,809.97 & 565.07 * & -628.94 \\ & & & \\ (705.00) & (1,480.24) & (287.49) & (748.09)\end{array}$

\section{DiD estimates}

2014* Group A

$\begin{array}{llllll}-290.84 & 1,542.16 & -257.28 & 3,436.16^{* * * *} & -185.33 & 1,910.25 \\ (590.38) & (1,148.99) & (713.98) & (1,027.77) & (952.43) & (3,038.23)\end{array}$

2014* Group B

$\begin{array}{llllll}-88.96 & -113.95 & -92.24 & 113.86 & -3.80 & 221.58\end{array}$

2014* Group E

$\begin{array}{llllll}(302.55) & (879.46) & (259.93) & (731.41) & (339.06) & (1,081.59)\end{array}$

$\begin{array}{llllll}-1,842.11^{* * * *} & -2,067.36 & -921.56^{* *} & -724.07 & -1,620.42^{* * * *} & -1,845.12\end{array}$

$\begin{array}{lllll}(625.02) & (1,480.78) & (382.90) & (879.80) & (447.35)\end{array}$

$\begin{array}{lcccccc}2015^{*} \text { Group A } & -1,465.72 * * * & 1,367.51 & -1,006.60 * * & 1,621.91 & -1,417.83 & 2,028.53 \\ 2015^{*} \text { Group B } & (482.71) & (3,296.55) & (394.13) & (1,505.61) & (954.05) & (3,043.39) \\ & -513.30 & -598.12 & -428.89 & -891.01 & -524.88 & -77.46 \\ 2015^{*} \text { Group E } & (373.44) & (1,164.04) & (301.88) & (803.98) & (341.53) & (1,089.48) \\ & -2,423.49 * * * & -1,327.15 & -1,447.11^{* * *} & 725.86 & -2,292.85 * * * & -890.81 \\ 2016^{*} \text { Group A } & (686.16) & (1,931.31) & (486.02) & (1,068.39) & (448.33) & (1,430.17) \\ & -1,230.74 * * & -846.01 & -957.43 * & 1,982.04 & -1,468.46 & -145.49\end{array}$




\begin{tabular}{|c|c|c|c|c|c|c|}
\hline \multirow[t]{2}{*}{ 2016* Group B } & -206.62 & 366.96 & -179.70 & 28.95 & -298.87 & 989.72 \\
\hline & $(314.17)$ & $(1,428.55)$ & $(278.92)$ & $(943.91)$ & $(343.84)$ & $(1,096.84)$ \\
\hline \multirow[t]{2}{*}{ 2016* Group E } & -943.13 & $-1,506.01$ & $-719.95 *$ & -709.93 & $-873.78 *$ & -919.12 \\
\hline & $(601.34)$ & $(2,186.26)$ & $(396.04)$ & $(990.48)$ & $(449.98)$ & $(1,435.43)$ \\
\hline \multicolumn{7}{|c|}{ Year dummies $($ ref. $=2012 \& 2013)$} \\
\hline \multirow[t]{2}{*}{2014} & $-781.83^{* * *}$ & 670.97 & $-961.37 * * *$ & 208.07 & $-1,252.32 * * *$ & 732.14 \\
\hline & $(239.92)$ & $(643.62)$ & (197.93) & $(480.55)$ & $(224.32)$ & (715.59) \\
\hline \multirow[t]{2}{*}{2015} & $624.91 * *$ & $2,358.28^{* * *}$ & 330.58 & $1,657.06 * * *$ & 275.66 & $2,438.56^{* * *}$ \\
\hline & $(290.11)$ & $(835.59)$ & $(202.95)$ & $(568.23)$ & $(221.94)$ & $(707.97)$ \\
\hline \multirow[t]{2}{*}{2016} & $1,270.76$ **** & $3,032.66^{* * * *}$ & $1,271.46^{* * *}$ & $1,962.80 * * *$ & $789.74 * * *$ & $3,222.99^{* * *}$ \\
\hline & $(229.51)$ & $(879.18)$ & (197.96) & $(581.52)$ & $(227.01)$ & $(724.17)$ \\
\hline \multicolumn{7}{|l|}{ Control variables } \\
\hline \multirow[t]{2}{*}{ Wealth per capita } & - & - & $0.07^{* * *}$ & $0.11^{* *}$ & $0.44^{* * *}$ & 0.04 \\
\hline & & & $(0.02)$ & $(0.05)$ & $(0.05)$ & $(0.17)$ \\
\hline \multirow[t]{2}{*}{ Expenditure needs per capita } & - & - & -674.20 & $-4,929.11$ & $\overline{-}_{10,082.19 * *}$ & $2,024.00$ \\
\hline & & & $(1,477.87)$ & $(4,799.12)$ & $(4,583.54)$ & $(14,621.41)$ \\
\hline \multirow[t]{2}{*}{ Population (ln) } & - & - & $175.05 *$ & -357.95 & $1,787.02$ & $-40,499.32 * * *$ \\
\hline & & & $(103.58)$ & $(304.33)$ & $(4,123.87)$ & $(13,155.06)$ \\
\hline \multirow[t]{2}{*}{ Constant } & $2,288.45^{* * *}$ & $10,091.43^{* * *}$ & $-2,797.91$ & $11,328.33 * *$ & $-27,282.84$ & $351,425.70^{* * *}$ \\
\hline & $(200.00)$ & $(485.94)$ & $(1,794.14)$ & $(5,592.04)$ & $(36,266.95)$ & $(115,690.85)$ \\
\hline Observations & 2,079 & 2,079 & 1,982 & 1,980 & 2,079 & 2,079 \\
\hline Number of municipalities & 416 & 416 & 415 & 416 & 416 & 416 \\
\hline Adj. $R^{2}$ & 0.052 & 0.016 & 0.137 & 0.036 & 0.083 & 0.062 \\
\hline $\max$ VIF & 2.566 & 2.566 & 2.402 & 2.230 & 2.584 & 2.584 \\
\hline
\end{tabular}

${ }^{* * *} \mathrm{p}<0.01, * * \mathrm{p}<0.05, * \mathrm{p}<0.1$. For models 1 and 2: Robust standard errors are in parentheses (clustered at each municipality). For models 3 and 4: Cases with Cook's D higher than 4/e(N) were excluded as outliers. For models 5 and 6 : The reported $\mathrm{R}^{2}$ is overall $\mathrm{R}^{2}$. 